\title{
The Effect of Blog-Based Teaching in 'Assessment and Evaluation' Course on Academic Achievement
}

\author{
Mustafa Akdağ \\ Faculty of Education, Inönü University, Malatya, Turkey \\ ORCID: 0000-0002-9128-9465 \\ İsmail Şan* \\ Faculty of Education, Inönü University, Malatya, Turkey \\ ORCID: 0000-0003-0780-0169
}

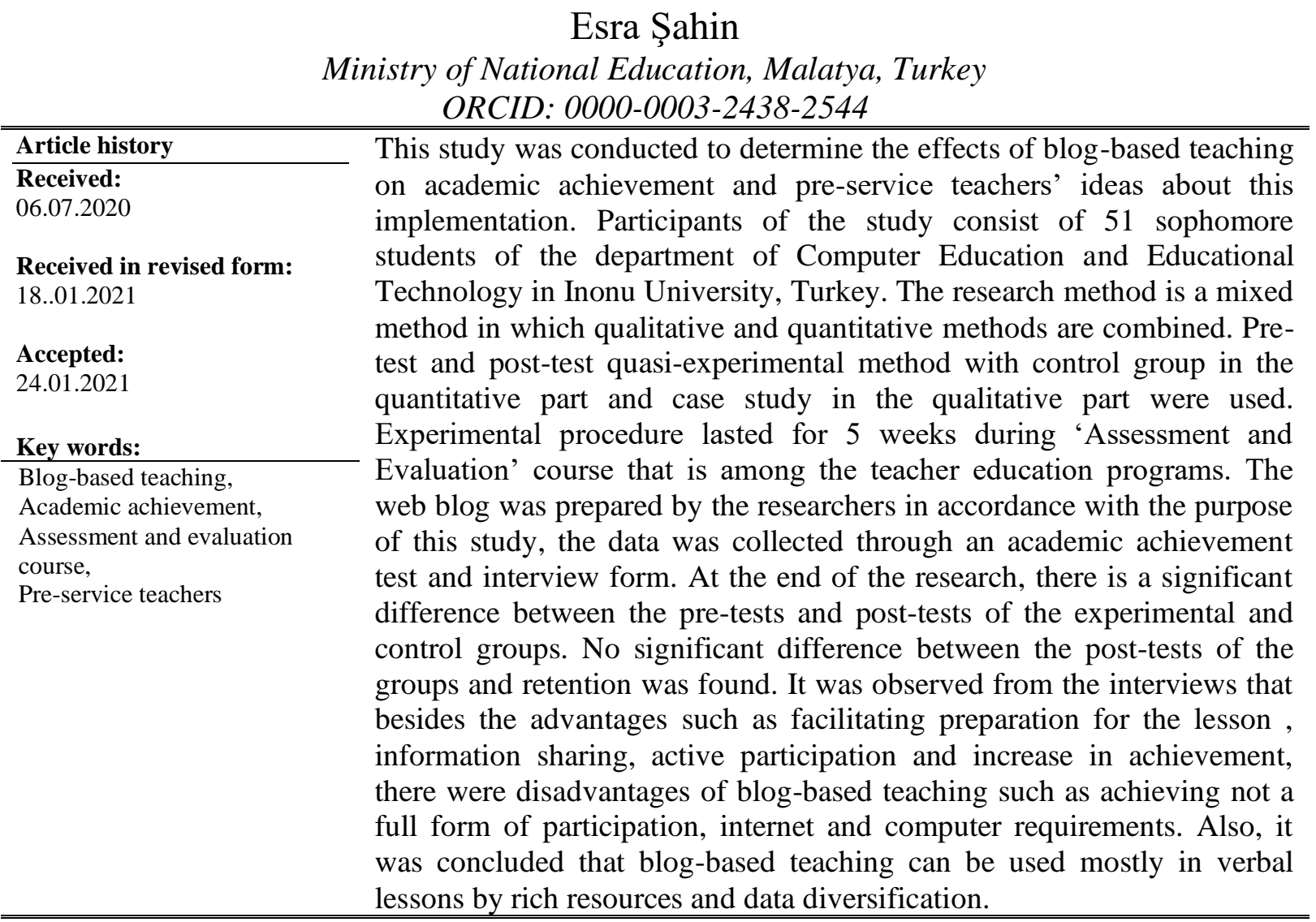

*Correspondency: ismail.san@inonu.edu.tr 


\section{Introduction}

In the current information age, factors such as the rapid increase in the amount of present information, social demand for education and as a result of this situation, increase in number of students, crowded classrooms, diversified information sources, change of teachers' roles and alike necessitate to differentiate the traditional teaching philosophy and processes. The rapid developments of science and technology affect every area of life. It is inevitable that these developments, especially innovations in information technology will be reflected to educational practices. Computer based teaching, distance education, web-based teaching which are based on the effective use of information technologies dismissed education from schools and made teaching services conducted independent of time and place.

Web based teaching is defined as learning-teaching process in which communication and interaction between the students and the organizers, directors, instructors of education are provided with the use of computer and network technologies (Demirli, 2002: 7). In web-based teaching practices, concepts such as traditional education, teacher, student are replaced by concepts such as e-learning, artificial intelligence applications and smart systems.

One of the practices of web-based teaching is blogs (online journal). Blog is a virtual and social environment of interaction where individuals share their feelings and thoughts about certain topics, where these sharings can be interpreted by other individuals, and in which shared information uploadings can be stored and updated by creating a chronological archive. Blogs differ from static web pages and forum discussions by their use without any coding knowledge (Baş \& Tüzün, 2007: 34-35; Wu, 2005: 426). Blogs are social media environments which have characteristics of an online personal journey that can be supported with written and visual materials, which can be commented on and through which comments can be stored, which could be linked to other websites easily (Şenel \& Seferoğlu, 2009: 143). It can be said that the level of digital literacy will be increased with the opportunity of researching on the topic while writing about it on the blog. Abilities such as creativity and originality develop because of feeling independent on the blog environment. These practices that are also social media environments contribute to the socialization of individuals. The fact that students can benefit from the enriched content on the blog pages according to their learning styles and needs serves to individualize the teaching.

Inclusion of blogs in the constructivist learning environment will increase the efficiency of education, especially process dimension of it (Şenel \& Seferoğlu, 2009: 143-144). Sharing course notes created on the virtual classroom environment, announcing the topics, distribution of homework and giving feedback by teachers while homework is being completed, providing guidance will provide an opportunity for versatile communication between the teachers and the students. Using the feature of instant reply (synchronous) can offer opportunities for problem solving and collaborative learning (Çakıroğlu, 2013: 133, 149). It is seen that blogs can also be used in the practises of "flexible learning supported by technology" (Flipped Learning) model (Kardaş \& Yeşilyaprak, 2015: 107) which provides time and place flexibility by using technology in the teaching process.

The reasons why use of blogs in Turkey is less than other countries are specified by Babur (2010: 14) as follows: using computer for having fun by the students, the attitudes of the students and their parents toward the computer and internet technology, financial impossibility regarding the access of technology, lack of computer and internet skills, being unable to encourage students, lack of teachers' knowledge about blogs, lack of equipment and infrastructure. 
Despite these advantages, the use of blogs for educational purposes increases day by day (Hong, 2008; Williams \& Jacobs, 2004; Yang, 2009). There are various advantages of using blogs in education. Convenience in evaluation for teachers, sharing experiences between the students, the development of written expression and language skills, contribution to meaningful and permanent learning, not having time problems, having an archive, developing the competence of using information technologies with active participation are some of them (Baş \& Tüzün, 2007: 37).

It can be said that studies of using blogs in education are generally limited to collecting data through interviews. In the research by Demirel (2010), participants stated the positive aspects of using blogs as ease of use, being free and enriching the design of the environment, while the negative aspects of it as limited choice of page design and being an open environment to inappropriate behaviours regarding copyright. In another study (Xie \& Sharma, 2004), enabling students to socialize by creating a suitable environment for critical and creative thinking as a positive aspect and possible problems regarding the correct use of blogs and privacy as a negative aspect of the topic are presented. Also, it is seen that use of blogs maximizes teamwork and socialization (Wang \& Fang, 2005), increases students' motivation toward the course (Çakıroğlu, 2013), has an impact on critical thinking skills (Babur, 2010) and levels of reflective thinking (Çiğdem, 2012). In two different experimental studies conducted at primary level (Babur, 2010; Bodur, 2010), it is seen that the use of blogs did not have a significant effect on students' academic achievement.

In this study, it was examined whether Blog Based Teaching has any impact on achievement in 'Assessment and Evaluation' course that is among the undergraduate programs in the Faculty of Education and also, the opinions and thoughts of the teacher candidates related to this teaching practice were tried to be determined. The results of the research are expected to contribute to experts of curriculum development and decision makers in the development of undergraduate programs in the Faculty of Education. It is thought that it will raise awareness of the instructors and teacher candidates who are the implementers of the curriculum of the efficiency of the teaching processes and the diversification of the educational environments. Additionally, it can be said that it will directly enhance teacher candidates' experiences in the planning, implementation and evaluation processes of Blog Based Teaching.

In line with the aims of this research, answers were sought to the following questions:

(1) Is there a significant difference between the pre-test and post-test scores of experimental group in terms of achievement?

(2) Is there a significant difference between the pre-test and post-test scores of control group in terms of achievement?

(3) Is there a significant difference between the post-tests scores of experimental and control groups in terms of achievement?

(4) Is there a significant difference between the retention scores of experimental and control groups?

(5) What are the opinions of students in experimental group regarding blog-based teaching practice?

\section{Method}

In this stage, study design, participants, data collection tools, experimental procedure and data analysis sub-titles are explained. 


\section{Study Design and Participants}

This study adopted a mixed method in which qualitative and quantitative methods are combined. Planning was made in accordance with an explanatory sequential mixed method from mixed method designs. The purpose of this design which consists of two stages is based on supporting, interpreting, or exemplifying the quantitative data obtained in the first stage with the qualitative data collected in the second stage (Creswell, 2017: 39).

In the quantitative part of the study, pre-test and post-test quasi-experimental method with control group and single case-holistic design that is one of the case study designs in the qualitative section were used. In this experimental design, the effect of Blog-based teaching which is applied to the experimental group on academic success was compared with data of the control group. In single case-holistic design, the unit of analysis is teacher candidates of the department of Computer Education and Educational Technology. In this design, the topics that are not studied much in the field are discussed. It is determined that this research has the requirements of single case-holistic design as it can be considered as an example for other studies because of the fact that the number of studies on Blog-based teaching based on the mixed research method has been detected as limited during the period of the application of this research (Yıldırım \& Şimşek, 2013: 326).

The participants of the study consist of teacher candidates who are sophomore students of the department of Computer Education and Educational Technology in İnönü or Inonu? Please stick to one of these University. After the students were grouped as odd and even numbers according to their student ID numbers, experimental and control groups were determined by random assignment. Two experimental group students who did not want to participate in the application were replaced with the students in the control group in a balanced way. There are 26 students in the experimental group and 25 students in the control group. The equivalence of the groups in terms of input behaviours prior to the experimental process was controlled by the pre-test. The results of independent sample t-test analysis are given below.

Table 1. t-test Results of Experimental and Control Groups Regarding Pre-Test

\begin{tabular}{lllllll}
\hline Groups & $\mathrm{n}$ & $\overline{\mathrm{X}}$ & $\mathrm{sd}$ & $\mathrm{df}$ & $\mathrm{t}$ & $p$ \\
\hline Experimental & 26 & 33.31 & 8.57 & \multirow{2}{*}{49} & \multirow{2}{*}{1.52} & 0.136 \\
Control & 25 & 28.72 & 12.72 & & & \\
\hline
\end{tabular}

As it can be seen from Table 1, there was no significant difference between the pre-test scores of groups $\left[\mathrm{t}_{(49)}=1.52, \mathrm{p}>0.05\right]$. This result shows that the students of both groups are equivalent in terms of the level of readiness.

\section{Data Collection Tools}

\section{Blog as Course Material:}

In line with the purpose of this study 'Assessment and Evaluation' Course Blog was for the experimental group was prepared by the researchers "https://inonuboteolcme.wordpress.com/". The site was presented to ask for three experts' opinions who are in the field of Computer and Instructional Technologies in terms of its compliance with design principles. There are main sections such as course materials, announcements, time of thinking, and guidelines on the site. In the course materials section, the lecture notes related to the topics covered in the study (scales, correlation, structural features of the measurement tool: "validity, reliability, usefulness") are included. In the 
announcements section, the activities requested by the instructor of the course before or after the lesson are specified. In the thinking time section, the questions to be answered by the students, the questions produced by the students, the answers given to these questions, the posts and comments made by the students and the instructor are included. In the guideline section, information about students' duties and responsibilities was shared throughout the process.

\section{Academic Achievement Test:}

Multiple choice achievement test developed by the researchers was used to determine the academic achievement of students. In the development of the test, first of all, pilot form consisting of 30 items was prepared by examining the resources related to the subjects. Then, the test items were presented to ask for the opinions of the instructors and the experts of educational science who give the 'Assessment and Evaluation' course focusing on content and face validity. Necessary corrections were made in line with the expert's feedback. In order to check the construct validity of the test, the pilot form was applied to a group of 81 junior and senior students who had taken this course before. Item analysis was done on the obtained data by using the upper and lower groups technique. As a result of the analysis, the test consisting of 22 items reached its final version. The reliability coefficient of the achievement test was calculated with the KR-20 formula as 0.81 , the average difficulty as 0.56 , and the average discrimination as 0.33 .

\section{Interview Form:}

The interview form was prepared to obtain the qualitative data of the research. In the interview form, there are five open-ended questions to determine the opinions, thoughts, and suggestions of the experimental group students about the blog application. In the preparation of the questions, the relevant literature was examined, and student observations were used. Necessary corrections were made with the examination of the questions by three experts and two students from the field of Educational Sciences (Examples of the questions: "In your opinion, what are the advantages and disadvantages of having this course as blog-based?, How can blog-based teaching be more effective, why?). The interview form was applied to 13 students randomly selected from the upper, middle, and lower experimental groups which were formed according to the means of retention scores at the end of the experimental process.

\section{Experimental Procedure}

The experimental procedure was carried out in 15 lesson hours (5 weeks) from February 25 to March 25, 2015 within the scope of 'Assessment and Evaluation' course under the responsibility of one of the researchers. Before the experimental process, the students were informed about the blog application (the structure and functioning of the blog, the expectations from the students during the process and at the end of it). The face-to-face part of the lessons was held in a traditional classroom environment in which there are experimental and control group students got together, additionally, the students in the experimental group participated in the teaching activities on the blog that was created for only themselves on the internet. As stated in the blog's guidelines page, the involvement of the students in the application was ensured, feedback was given by following their activities, synchronous-asynchronous posts were made, and face-to-face interviews were made when it was necessary. At the end of the experimental procedure, students were asked to prepare a portfolio as an assignment. Three of the portfolios that are considered as worth sharing are 
published on the blog site. At the end of the experimental procedure, academic achievement test was applied to the groups as post-test, and interview was applied to the selected students in the experimental group. The students were asked to answer the interview questions in written form.

\section{Data Analysis}

In the analysis of the quantitative data of the research, arithmetic mean, standard deviation and t-test were used. The normality of the scores obtained from the achievement test was checked with the Kolmogorov-Smirnov test, and the equality of the variances was checked with the Levene test. As a result of these tests, it was observed that the score distributions of the groups met the assumptions of normality and the variances were equal. Independent sample t-test was used to compare the pre-test, post-test, and retention scores (the difference between pre-test scores and post-test scores) of the groups, and dependent sample t-test for the comparisons within the groups. The students' scores from the achievement test were calculated over 100 points. Statistical analyses were made in computer environment by using a ready package software. Qualitative data obtained from the interview form were analysed by descriptive analysis method.

In the descriptive analysis, it was determined that under which themes the data would be presented by examining the relevant literature and taking interview questions and subdimensions into consideration, the data was coded in the created framework of the themes, and the opinions of the students which are about the same codes and themes were tabulated according to the frequency of repetition. The reliability of the coding was checked by comparing the similarities and differences in the coding realized by the two researchers separately.

The data that is organized in this way is supported by direct quotations and interpreted. In the direct quotations, the participants were defined as "S1, S2, .. .S13".

\section{Findings}

In this section, there are analysis of the research questions.

\section{The Findings of Pre-test and Post-test Scores of Experimental Group on Achievement:}

At the end of the experimental procedure, the post-test was applied to the experimental group and dependent sample t-test analysis was done to determine whether there was a significant difference between the pre-test and post-test mean scores of the group. The results of analysis are presented in Table 2.

Table 2. t-test Results of Pre-test and Post-test Scores of The Experimental Group

\begin{tabular}{lllllll}
\hline Tests & $\mathrm{n}$ & $\overline{\mathrm{X}}$ & $\mathrm{sd}$ & $\mathrm{df}$ & $\mathrm{t}$ & $p$ \\
\hline Pre-test & 26 & 33.31 & 8.57 & \multirow{2}{*}{25} & \multirow{2}{*}{14.27} & $0.00^{*}$ \\
Post-test & 26 & 62.41 & 10.88 & & & \\
\hline
\end{tabular}

In the analysis of the data from Table 2, it is demonstrated that post-test average score of the experimental group $(\bar{X}=62.41)$ is higher than the pre-test average score of it ( $\bar{X}=33.31$ ). As a result of the analysis, the difference between the average scores was found statistically significant $\left[\mathrm{t}_{(25)}=14.27, \mathrm{p}<.05\right]$. 


\section{The Findings of Pre-test and Post-test Scores of The Control Group on Achievement:}

The significance of the difference between the pre-test and post-test average scores of the control group was analysed by a dependent sample t-test. The obtained results are given in the table below.

Table 3. t-test Results of Pre-test and Post-test Scores of The Control Group

\begin{tabular}{lllllll}
\hline Tests & $\mathrm{n}$ & $\overline{\mathrm{X}}$ & $\mathrm{sd}$ & $\mathrm{df}$ & $\mathrm{t}$ & $p$ \\
\hline Pre-test & 25 & 28.72 & 12.72 & 24 & \multirow{2}{*}{10.02} & $0.00^{*}$ \\
Post-test & 25 & 59.09 & 14.49 & & & \\
\hline
\end{tabular}

$* p<.05$

According to the results of the analysis, a significant difference was observed in the academic achievement of the control group students in favor of the post-test $(\bar{X}=59.09)\left[\mathrm{t}_{(24)}=10.02\right.$, $\mathrm{p}<.05]$.

\section{The Findings of Post-test Scores of The Experimental and Control Group on Achievement:}

Independent sample t-test analysis was conducted to determine whether the difference between the post-test average scores applied to the groups at the end of the experimental procedure was significant. The results of analysis are presented in Table 4 .

Table 4. t-test Results of Post-tests Scores of The Experimental and Control Groups

\begin{tabular}{lllllll}
\hline Groups & $\mathrm{n}$ & $\overline{\mathrm{X}}$ & $\mathrm{sd}$ & $\mathrm{df}$ & $\mathrm{t}$ & $p$ \\
\hline Experimental & 26 & 62.41 & 10.88 & 49 & 0.93 & 0.36 \\
Control & 25 & 59.09 & 14.49 & & & \\
\hline
\end{tabular}

According to the data of the table above, the post-test average $(\bar{X}=62.41)$ of the experimental group is higher than the post-test average $(\bar{X}=59.09)$ of the control group. As a result of the analysis, the difference between these averages was not found statistically significant $\left[t_{(49)}=\right.$ $.93, \mathrm{p}>.05]$.

\section{The Findings of Retention Scores of The Experimental and Control Group:}

In order to interpret the post-test results of the groups better, it was examined whether the difference between the post-test and pre-test scores (retention scores) of both groups was significant. The results of independent sample t-test are given in Table 5.

Table 5. t-test Results of Retention Scores of The Experimental and Control Groups

\begin{tabular}{lllllll}
\hline Groups & $\mathrm{n}$ & $\overline{\mathrm{X}}$ & $\mathrm{sd}$ & $\mathrm{df}$ & $\mathrm{t}$ & $p$ \\
\hline Experimental & 26 & 29.10 & 10.40 & 49 & 0.35 & 0.73 \\
Control & 25 & 30.37 & 15.16 & & & \\
\hline
\end{tabular}

It is seen from Table 5 that the average retention scores of the experimental and control groups ( $\bar{X}=29.10, \bar{X}=30.37$ ) are very close to each other. As a result of the analysis, there was no statistically significant difference between the average retention scores of the groups $\left[\mathrm{t}_{(49)}=.35, \mathrm{p}>.05\right]$.

\section{The Findings Regarding Students' Opinions:}

An interview form was applied to some of the experimental group students $(n=13)$ in order to get their opinions, thoughts, and suggestions about Blog-based teaching. The 
obtained data were organized under the themes of "advantages of Blog-based teaching", "disadvantages of Blog-based teaching", "the effective use of Blog-based teaching" and "the lessons in which Blog-based teaching can be applied", and the findings are presented in Table 6.

Table 6. Students' Opinions on Blog-based teaching

\begin{tabular}{|c|c|c|}
\hline Opinions & $\mathrm{f}$ & Participants \\
\hline \multicolumn{3}{|l|}{ Opinions on The Advantages of Blog-based teaching } \\
\hline Facilitating lesson preparation & 6 & S1, S2, S6, S8, S9, S13 \\
\hline Sharing information & 6 & $\mathrm{~S} 4, \mathrm{~S} 6, \mathrm{~S} 8, \mathrm{~S} 9, \mathrm{~S} 10, \mathrm{~S} 11$ \\
\hline Increasing the interest in the lesson, active participation & 5 & $\mathrm{~S} 1, \mathrm{~S} 2, \mathrm{~S} 5, \mathrm{~S} 11, \mathrm{~S} 12$ \\
\hline Increasing the course achievement & 5 & $\mathrm{~S} 3, \mathrm{~S} 10, \mathrm{~S} 11, \mathrm{~S} 12, \mathrm{~S} 13$ \\
\hline Being fun, interesting, interactive & 2 & $\mathrm{~S} 2, \mathrm{~S} 11$ \\
\hline Always asking questions & 2 & $\mathrm{~S} 2, \mathrm{~S} 11$ \\
\hline Having graphics, sound, animation & 1 & $\mathrm{~S} 2$ \\
\hline \multicolumn{3}{|l|}{ Opinions on The Disadvantages of Blog-based teaching } \\
\hline Not always participating in the classes & 6 & $\mathrm{~S} 3, \mathrm{~S} 5, \mathrm{~S} 6, \mathrm{~S} 8, \mathrm{~S} 9, \mathrm{~S} 11$ \\
\hline Internet and computer requirements & 5 & $\mathrm{~S} 2, \mathrm{~S} 3, \mathrm{~S} 5, \mathrm{~S} 9, \mathrm{~S} 12$ \\
\hline Time consuming & 3 & $\mathrm{~S} 2, \mathrm{~S} 5, \mathrm{~S} 8$ \\
\hline Requirement of more work & 2 & $\mathrm{~S} 1, \mathrm{~S} 2$ \\
\hline Possibility of misinformation & 2 & $\mathrm{~S} 10, \mathrm{~S} 11$ \\
\hline Difficulty in expressing yourself & 1 & S9 \\
\hline Blocking creativity & 1 & $\mathrm{~S} 2$ \\
\hline Not listening to the lecture & 1 & $\mathrm{~S} 1$ \\
\hline \multicolumn{3}{|l|}{ Opinions on The effective use of Blog-based teaching } \\
\hline Increasing participation & 4 & $\mathrm{~S} 1, \mathrm{~S} 4, \mathrm{~S} 8, \mathrm{~S} 13$ \\
\hline Different kinds of sources & 4 & $\mathrm{~S} 3, \mathrm{~S} 5, \mathrm{~S} 8, \mathrm{~S} 10$ \\
\hline Strict control & 2 & S7, S13 \\
\hline Using reward system & 1 & S11 \\
\hline Meeting students' needs & 1 & S13 \\
\hline \multicolumn{3}{|c|}{ Opinions on The Lessons in which Blog-based teaching can be applied } \\
\hline Verbal lessons & 8 & S2, S5, S6, S7, S8, S9, S10, S12 \\
\hline Programming languages & 3 & $\mathrm{~S} 1, \mathrm{~S} 4, \mathrm{~S} 11$ \\
\hline Assessment and evaluation & 1 & $\mathrm{~S} 1$ \\
\hline English language & 1 & S11 \\
\hline
\end{tabular}

It is visible from Table 6 that the advantages of Blog-based teaching are facilitating lesson preparation $(\mathrm{f}=6)$, opportunity for sharing information $(\mathrm{f}=6)$, increasing the interest in the lesson, active participation ( $\mathrm{f}=5)$ and increasing the course achievement $(\mathrm{f}=5)$. Some of the students' opinions are as follows:

"It helps us to come prepared for the lesson. It enables us to be active in the lesson. It provides a sense of confidence in the class. It enables us to participate in the lesson. It is fun, interesting, and entertaining. There is an opportunity to ask questions whenever we want. It has graphics, sound and animation." (S2)

"In this blog, students learn about the subject of upcoming lessons. They come prepared for the subject. Questions, information, examples shared on the blog help us better understand the subject. Thanks to the blog, the student searches for the answers for the questions, and learns about other subjects besides the answers." (S6)

"One of the advantages is reinforcement of the lesson of that day with questions until the next lesson and driving us to repeat the lesson content. We are in the age of technology 
but there may be some problems. Having a conversation, exchange of ideas like we do in a classroom with our classmates is also an advantage." (S9)

It is understood from the findings on the theme of the advantages of the implementation that the students attach more importance to the features of facilitation in lesson preparation and information sharing.

As can be seen from Table 6, the majority of the participants stated that Blog-based teaching has disadvantages such as not always participating in the site $(\mathrm{f}=6)$, internet and computer requirements $(\mathrm{f}=5)$, being time consuming $(\mathrm{f}=3)$. Some of the answers are as follows:
"All the students may not participate. It may not be possible to do this regularly by a student. It may not be possible to continue this study for a long time. It may not direct the students to do research. The students may not be able to access the website every day." (S5)
"It requires special equipment and skills. It is time consuming. The internet is required. Effective use of computer is needed. It may block students' creativity." (S2)
"It may not be a good way for the students who do not have an internet access. Students may not attend the system regularly. Students who do understand the subject in the lesson may fail at the system because of being on the back burner." (S3)

The ones that draw the most attention from the opinions are not always participating on the site and requiring a computer with internet support.

It is understood that the prominent opinions on the effective use of Blog-based teaching are student participation and resource diversity $(\mathrm{f}=4)$. Some of the information given by the participants is as follows:

"It should provide access to resources such as books, websites and blogs that will be supportive for the subjects covered in the lessons. It should enable different instructors to share information about the course on the blog page. It should be ensured that all the students benefit from the blog. If these are taken into consideration, all the students can benefit from the blog with the help of more different, more effective and more permanent information sharing." (S8)

"If both visual and verbal materials are used in the blog and posts are updated with the subjects, it may be more effective." (S10)

"First of all, strict control is needed. In the beginning, it may be difficult and boring for the students to do in this way, but then, all the information we will receive will be in our favor. The learned topics will never be wasted and will be used somewhere." (S7).

Eight of the participants stated that it would be appropriate to use Blog-based teaching in verbal lessons, and three of them stated Programming Languages. Some of the opinions are given below.

"This method can be used for more verbal and interpretative lessons. It is not useful to refer to a blog for practical lessons. Sharing notes, commenting, sharing questions in verbal lessons make the information of the lesson more permanent because it is more temporary. Thanks to the blog application, we can make it more permanent." (S5)

"It is for 'Assessment and Evaluation' and 'Programming Languages' courses because you can try it beforehand and get help from the classmates and the instructor, so, learn with fun." (S1) 
It is understood that the verbal courses are prominent in the analysis of the lessons in which blog-based teaching can be more effective.

\section{Results, Discussion and Recommendations}

In this study in which the effect of blog-based teaching on academic achievement was investigated, firstly, achievement of the experimental and control groups before and after the experimental procedure were examined. For this purpose, average scores of the pre-test and post-test of the groups were compared, and as a result of the analyses, significant differences were found in favor of the post-tests in both groups. Based on this result, it can be said that both Blog-based teaching and traditional teaching method increased academic achievement. When the averages of the post-test of the groups are examined, a difference of 3.32 was observed in favor of the experimental group. However, this difference is not statistically significant. In the comparison of the retention scores of the groups, as in the comparison of the post-test scores, there was no significant difference between the averages of the groups. These results can be interpreted that Blog-based teaching and traditional teaching have a similar and positive effect on the course achievement. It is seen from the literature review that there are studies in various courses on blog application that did not have the expected effect on academic achievement, as in this study. For example, in an experimental study (Glymph, 2012), in which the impact of a private classroom blog on Spanish writing skills were examined, no significant differences were observed in completing the differences, comprehensibility, level of discourse, vocabulary and language control skills. In a study conducted within the scope of 'Information Technology' course (Babur, 2010), it was seen that the average of the achievement score of the experimental group was higher than the control group, but the difference was not significant. In the study by Erickson (2009), there was no significant difference between the academic achievements of the Science students who studied in the blog environment and the students who studied in a traditional environment. In the study conducted by Fong (2012), it was determined that the blog application which provides a reflective learning environment does not have a positive effect on the learning outcomes. Research findings suggesting that Blog-based teaching increases student achievement are also encountered in the literature (Çuhadar, 2008; Du \& Wagner, 2005; Kurt, İzmirli \& Şahin 2011).

In this study, the unconfirmed research hypothesis which can be expressed as "Blog-based teaching is more effective than traditional teaching on academic achievement" can be interpreted in various ways. First of all, the reason for this can be searched in the answers given to the question "What are the disadvantages of Blog-based teaching?". It is understood from the analysis of qualitative findings on this theme that the majority of students cannot always join the blog site $(\mathrm{f}=6)$, and the most important reason for this is the need for internet and computer $(f=5)$ (See Table 6). This and similar technological requirements may be the most important reason why Blog-based teaching does not have the expected effects on academic achievement. Related research reveals that the challenges of internet access prevent following the web logs regularly (Bodur, 2010; Koçoğlu, 2009; Kurt et al., 2011). Apart from the technological requirements, another reason for the students not always participating in the blog site may be the inadequacy of informational meeting for one hour about the blog application (opening an account, membership, obligations in the procedure, and so on.) before the experimental procedure. Some studies have shown that students need information about how to use blogs (Kerawalla, 2007; Şahin K1z1l, 2007). Various student-oriented problems may also be a reason for the unconfirmed research hypothesis. In a study by Tajeddin \& Aghababazadeh (2018), irregular participation in the lessons, not having a strong sense of 
responsibility, motivation and self-reliance problems due to the undeveloped self expression skills in the blog environment are defined as student-oriented problems. The difference of internet usage habits is also an important reason. The studies show that t-university students mostly use the internet for communication/chat, entertainment, searching for general information except for the lesson content, reading newspaper-magazines, playing games and watching videos not for educational purposes (Akdağ, Şahan Y1lmaz, Özhan \& Şan, 2014; Durmuş et al., 2018; Nazik \& Güneş, 2019; Pektaş \& Mayda, 2018). Conditions of the experimental procedure (probability of similarity and assistance in information sharing except the lessons due to the fact that the experimental and control group students were from the same department) and the learning habits of the students can be considered as reasons for the unconfirmed the research hypothesis. It can be said that blog activities in which the students are more active may conflict their learning habits because of the traditional lessons for which the instructor is more active before and throughout the experimental procedure. Thus, it was observed in a study (Coutinho, 2007) that students were not accustomed to work cooperatively in blog-based teaching due to the traditional teaching method.

In this research, it was concluded that Blog-based teaching may have disadvantages such as being time consuming, requiring more work, the possibility of misinformation, and blocking creativity other than the above-mentioned disadvantages.

In addition to increasing the academic achievement by Blog-based teaching, student interviews showed that it has advantages such as facilitating lesson preparation, sharing information, increasing interest in the lesson and active participation. These results show that the blog can be used in flipped learning (FLN, 2014) model in which the students work on the subject before coming to class and do practical studies in the classroom. It was found that Blog-based teaching have advantages such as arousing interest and providing experience in collaborative work (Hong, 2008; Kitchakarn, 2014; Ray \& Hocutt 2006; Şahin Kız1l, 2007); sharing information, developing different perspectives, giving peer feedback, and socializing (Bayrak, 2010; Çuhadar \& Kuzu, 2010; Demirel, 2010; Lin \& Hooft, 2008; Neira-Piñeiro, 2015; Şenel \& Seferoğlu, 2009; William \& Jacobs, 2004). Relevant findings regarding critical thinking (Babur, 2010) and reflective thinking skills (Çiğdem, 2012; Mynard, 2007; Shoffner, 2006) were also found.

Considering these features revealed by the scientific research, it can be said that Blog-based teaching is appropriate for Research based strategy that provides problem-solving skills for the students.

Prominent opinions of students on the effective use of Blog-based teaching are increasing student participation and diversification of resources. When the research findings are examined (see Table 6), it is noteworthy that only one participant regards the blog site positively in terms of graphics, sound, and animation features. This data can be considered as a missing part of the blog as course material. The content of the blog pages should be enriched with a variety of data such as text, images, figures, graphics, sounds, animations, and videos which are suitable for the objectives of the course. It has been seen that adding videos to the blog environment for the students who have different learning styles offers learning opportunities that are appropriate for the interests and needs of the students and provide more participation (O'Byrne \& Murrell, 2014; Türker \& Genç, 2018). It can be said that the suggestions stated as "strict control" and "using the reward system" should be taken into consideration in increasing the student participation in the blog site. As a matter of fact, it was concluded that the students who follow the blogs regularly are more successful in the research 
conducted by Atıc1 and Özmen (2011). Within the scope of this research, the entrance and exit acts of the students were tracked and shared with the students. In addition, students were motivated announcing that three of the most successful portfolios would be published on the blog site.

The analysis of students' opinions on the lessons in which blog-based teaching will be more effective pointed to verbal lessons. This conclusion shows that blog-based teaching can be used in the lessons with cognitive learning based on mental activities (Arrival, 1978; 154) and descriptive content including the answers toward the questions such as 'what happened?, where, when ?, who did it?' and normative content including the answers toward the questions such as 'why did it happen?, would it happen again?, is it good or bad?, how should it be?' (Varış, 1978; 154). It can be said that the structure of the content of 'Assessment and Evaluation' course in which this research is carried out and the subjects (scales, correlation, structural features of the measurement tool: 'validity, reliability, usefulness') were suitable with these features. It is observed from the analysis of literature review that Blog-based teaching was effective in Science lessons (Bodur, 2010), in foreign language teaching (Yeh, Tseng \& Chen, 2017), and especially in the development of writing skills (Akdağ \& Özkan, 2017; Fellner \& Apple, 2006; Kitchakarn, 2014; Sullivan \& Longnecker, 2014; Şahin Kızıl, 2007). Bayrak \& Usluel (2011) concluded that web logs will be effective in practical and verbal courses. The statement of the use of Blog-based teaching in "Programming Languages" course may be because of the participants who are the students of the "Computer and Instructional Technology Teaching" department. Additionally, partial implementation of it in the "Programming Languages" course, the need for mutual interaction and information sharing may be a reason for this. It is remarkable that the implementation of blog-based teaching in "Assessment and Evaluation" course in which this study is conducted by one participant and the implementation of it in "English" by one participant were stated. The most important reason for this may be that some participants did not mention the content of the course at the end of the interview, they just named the courses. In fact, it can be said that the content of these courses is verbal in general.

Depending on the results achieved in the research, the following recommendations can be made for practitioners and researchers.

\section{Recommendations for Practitioners:}

Blog-based teaching can be used in verbal courses in which cognitive skills are gained and in the teaching of theoretical parts of courses that provide psychomotor skills. For this purpose, in-service trainings about Blog-based teaching can be organized for instructors.

- The web log should be prepared in accordance with the web design principles enriched with a variety of data such as documents, images, figures, graphics, sounds, animations, and videos which are suitable for the objectives of the course.

- Blog entrance and exits by students and their participation in activities should be regularly monitored, and warnings should be used as the need arises.

- Appropriate reinforcers (rewards, grades, and others.) should be provided to encourage active participation of students on the blog.

- Students should be informed about the features, instructions, and advantages of Blogbased teaching.

- The opportunities for internet usage of students should be diversified. In this purpose, planning should be made for students to benefit from the computer labs located in the 
faculty buildings and used for educational purposes, outside the internet cafe located in the campus.

- Technological infrastructure deficiencies should be eliminated in order to avoid disruptions in on-campus and off-campus internet access that students can use free of charge.

\section{Recommendations for Researchers:}

- The effect of Blog-based teaching on academic achievement can be examined through experimental research on different subjects and with different sample groups.

- Studies which examine the effects of Blog-based teaching on different variables (interest, motivation, problem solving, teaching, and learning styles) can be conducted.

- In order to develop the theoretical framework (features, guidelines for the preparation and use of Blog-based teaching, advantages, limitations), qualitative studies based on document analysis and interview technique (with the experts of curriculum development, educational technologists, psychologists, teachers) can be conducted.

Note

This paper was presented as a platform presentation at The 3rd International Congress on Curriculum and Instruction, October 22-24, 2015, Adana, Turkey

\section{References}

Akdağ, E. \& Özkan, Y. (2017). Enhancing writing skills of EFL learners through blogging. The Reading Matrix: An International Online Journal,17(2), 79-95.

Akdağ, M., Şahan Yılmaz, B., Özhan, U. \& Şan, İ. (2014). Examining the internet addiction of university students in terms of various variables. Inonu University Journal of the Faculty of Education, 15(1), 73-96.

Atıc1, B. \& Özmen, B. (2011). The effect of using blog on class community feeling. Educational Technologies Research Journal, 3(1).

Babur, A. (2010). The effect of teaching the unit " $i$ am starting publishing" in fifth class information technology course on students' critical thinking, academic success and the knowledge retention at bolu gazipaşa primary school, Unpublished Master Thesis, Gazi University, Ankara.

Baş, T. \& Tüzün, H. (2007). Using blogs in prospective teachers' field practice, Proceedings Book of the International Conference on Teacher Training Policies and Problem, Baku-Azerbaycan, 2007, pp. 34-38.

Bayrak, F. \& Usluel, Y. (2011). The effect of blogging on reflective thinking skill. Hacettepe University Journal of Education, 40, 93-104.

Bayrak, F. (2010). The effect of blogging on reflective thinking skill, Unpublished Master Thesis, Hacettepe University, Ankara.

Bodur, E. (2010). The effect of weblogs in cooperative science education: application on secondary school students, Unpublished Master Thesis, Ege University, İzmir.

Coutinho, C. P (2007). Cooperative learning in higher education using weblogs: a study with undergraduate students of education in Portugal. World multi-conference on systemics, cybernetic and informatics, 11, Orlando, USA, 2007 - "WMSCI 2007". [S.1. : s.n.], 2007. ISBN 1934272116. vol. 1, p. 60-64 
Creswell, J. W. (2017). Introduction to mixed method researches. (M. Sözbilir, Trans.). Ankara: PegemA Publishing. (Original work published 2014).

Çiğdem, H. (2012). The effect of journals that prospective teachers of information technologies have kept in the teaching practicum courses through blog on reflective thinking levels, Unpublished Doctoral Dissertation, Anadolu University, Eskişehir.

Çuhadar, C. \& Kuzu, A. (2010). Improving interaction through blogs in a constructivist learning environment. Turkish Online Journal of Distance Education-TOJDE 11(1), 134-161.

Çuhadar, C. (2008). Improving interaction through blogs in a constructivist learning environment. Unpublished Doctoral Dissertation, Anadolu University, Eskişehir.

Demirel, T. (2010). Preservice teachers? views on instructional use of blogs, Unpublished Master Thesis, Atatürk University, Erzurum.

Demirli, C. (2002). The effect of Web based teaching on students achievement in instructional technologies and material development course (The sample Technical Education Faculty of F.U.), Unpublished master thesis, Firat University, Elazığ.

Du, H. S. \& Wagner, C. (2005, January). Learning with weblogs: an empirical investigation. Proceedings of the 38th Annual Hawaii International Conference on System Sciences (pp. 1-9). IEEE. Retrieved from:http://ieeexplore.iee.org/stamp/stamp.jsp $? \mathrm{tp}=$ \&arnumber $=1385240$

Durmuş, H., Günay, O., Yıldız, S., Timur, A., Balc1, E. \& Karaca, S. (2018). Internet addiction in university students and change through university life. Anatolian Journal of Psychiatry, 19(4), 383-389.

Erickson, D. K. (2009). The effects of blogs versus dialogue journals on open-response writing scores and attitudes of grade eight science students. Unpublished Doctoral Dissertation, University of Massachusetts Lowell, USA.

Fellner, T. \& Apple, M. (2006). Developing writing fluency and lexical complexity with blogs. The JALT CALL Journal 2(1).

Definition of Flipped Learning. (2019, January 18). Retrieved July 06, 2020, from https://flippedlearning.org/definition-of-flipped-learning/

Fong, R. C. W. (2012). Student perceptions and learning approaches of using blogs in $t$ education for reflection and knowledge construction. Unpublished Doctoral Dissertation, Durham University, UK.

Glymph, O. G. (2012). The effect of the private classroom blog on the acquisition of formal writing proficiency with spanish III high school students. Unpublished Doctoral Dissertation, Liberty University, Lynchburg, VA.

Hong, W. (2008). Exploring educational use of blogs in U.S. education, US-China Education Review, 5(10), 34-38.

Kardaş, F \& Yeşilyaprak, B. (2015). A current approach to education: Flipped learning model. Ankara University Journal of Faculty of Educational Sciences (JFES), 48(2), 103-121.

Kerawalla, L. (2007). Exploring students' understanding of how blogs and blogging can support distance learning in higher education. ALT-C 2007 Research Proceedings.

Kitchakarn, O. (2014). Developing writing abilities of efl students through blogging. Turkish Online Journal of Distance Education-TOJDE 15(4).

Koçoğlu, Z. (2009). Weblog use in EFL writing class. Ankara University Journal of Faculty of Educational Sciences, 42(1), 311-327.

Kurt, A. A., İzmirli, S. \& Şahin İzmirli, Ö. (2011). Student experience in blog use for supplementary purposes in courses. Turkish Online Journal of Distance EducationTOJDE 12(3). 
Lin, Y. M. \& Hooft, M. (2008). The impact of blogs on student perceptions toward social interaction and learning satisfaction in blended learning. International Conference on Computers in Education, Taipei-Taiwan.

Mynard, J. (2007). A blog as a tool for reflection for English Language learners. The Asian EFL Journal, 24 (November), 1-10.

Nazik, F. \& Güneş, G. (2019). Problematic internet usage and healthy lifestyle behaviors in university students. Cukurova Medical Journal, 44(Suppl 1), 41-48.

Neira-Piñeiro, M. R. (2015). Reading and writing about literature on the internet. Two innovative experiences with blogs in higher education, Innovations in Education and Teaching International, 52(5), 546-557.

O'Byrne, B. \& Murrell, S. (2014). Evaluating multimodal literacies in student blogs. British Journal of Educational Technology, 45(5), 926-940.

Pektaş, İ. \& Mayda, A. S. (2018). The level of internet addiction and affecting factors in medical school students. Sakarya Medical Journal, 8(1), 52-62.

Ray, B. B. \& Hocutt, M. M. (2006). Teacher-created, teacher-centered weblogs: perceptions and practices. Journal of Computing in Teacher Education, 23(1).

Shoffner, M. (2006). "We don't have the liberty of being brainless": exploring pre-service teachers' use of weblogs for informal reflection. Unpublished Doctoral Dissertation, University of North Carolina, Chapel Hill.

Sullivan, M. \& Longnecker, N. (2014). Class blogs as a teaching tool to promote writing and student interaction. Australasian Journal of Educational Technology, 30(4), 390-401.

Şahin Kızıl, A. (2007). A Quasi experimental study on the effect of weblog integrated process approach on efl students' writing performance, autonomous learning and perceptions, Unpublished Master Thesis, Karadeniz Technical University, Trabzon.

Şenel, H. C., \& Seferoğlu, S. S. (2009). Blog activities in education: examples from elementary school computer courses). In Proceedings of 9th International Educational Technology Conference (IETC-2009) (pp. 142-148).

Tajeddin, Z. \& Aghababazadeh, Y. (2018). Blog-mediated reflection for professional development: exploring themes and criticality of 12 teachers' reflective practice. Tesl Canada Journal, 35(2).

Türker, M. S. \& Genç, A. (2018). Students' and teachers' views on instructional use of blogs in teaching turkish as a foreign language. Selçuk University Journal of Faculty of Letters, 2018(39), 251-266.

Varış, F. (1978). Curriculum development in education: Theory and techniques. Ankara: Ankara University Faculty of Education Publications.

Wang, J. \& Fang, Y. (2005). Benefits of Cooperative Learning in Weblog Networks. Received from: ERIC database, Number: ED490815.

Williams, J. B. \& Jacobs, J. (2004). Exploring the use of blogs as learning spaces in the higher education sector. Australasian Journal of Educational Technology, 20(2), 232247.

Wu, W. S. (2005). Using Blogs in an EFL Writing Class. Received from: http://people.chu.edu.tw/ wswu/publications/papers/book_chapters/01.Pdf

Xie, Y. \& Sharma, P. (2004). Students lived experience of using weblogs in a class an exploratory. Association for Educational Communications and Technology.

Yang, S. H. (2009). Using blogs to enhance critical reflection and community of practice. Educational Technology \& Society, 12 (2), 11-21.

Yeh, H. C., Tseng, S. S. \& Chen, Y. S. (2017). Using online peer feedback through blogs to promote speaking performance, Educational Technology \& Society, 22(1), 1-14.

Yıldırım, A. \& Şimşek, H. (2013). Qualitative research methods in the social sciences. Ankara: Seçkin Publishing. 